\title{
A Portable Refraction
}

Seismograph Survey of

Gold Placer Areas Near

Nome, Alaska

By H. GARY GREENE

\section{CONTRIBUTIONS TO ECONOMIC GEOLOGY}

GE OLOGICAL S URVEY B ULLETIN 1312-B

A seismic refraction investigation on the beach and tundra areas near Nome, Alaska, with emphasis on placer gold exploration

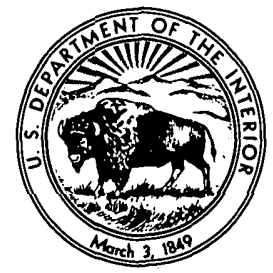




\title{
UNITED STATES DEPARTMENT OF THE INTERIOR
}

WALTER J. HIGKEL, Secretary

\author{
GEOLOGICAL SURVEY
}

William T. Pecora, Director

For sale by the Superintendent of Documents, U.S. Government Printing Office Washington, D.C. 20402 - Price 60 cents (paper cover) 


\section{CONTENTS}

Pago

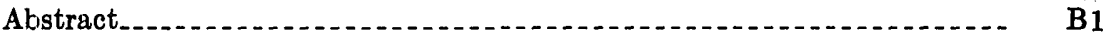

Introduction . . . . .

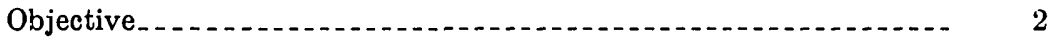

Location . . .

Geologic setting

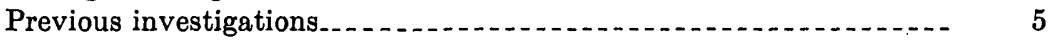

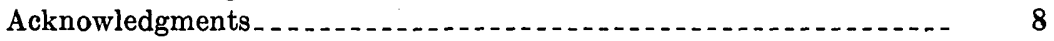

Equipment and procedures........ 8

Equipment_ _.

Experimental survey.... 9

Procedures.

Interpretation of seismograms...

Theory

Plotting of data

Results_...

Beach profile........ 18

Tundra survey

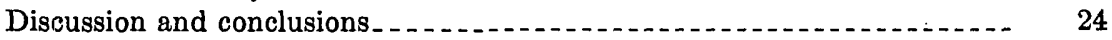

Interpretation ........... 24

Potential placer sites............. 27

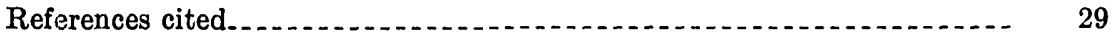

\section{ILLUSTRATIONS}

Page

Plate 1. Beach-survey map, showing location of beach seismic stations and composite basement contours, with cross section, expanded beach profile, and geophone spreads.......... In pocket

Figtre 1. Index map of Alaska, showing survey area....................

2. Map of southwestern Seward Peninsula, showing location of beach and tundra investigation sites....................

3. Generalized geologic map and cross section of the coastal plain at Nome.

4. Seismograms obtained with blasting-cap and dynamite sound sources.

5. Time-distance graph and schematic representation of refraction of seismic energy at three acoustical interfaces........-

6. Refraction seismogram, showing how first-arrival times are picked and plotted on a time-distance graph............

7. Time-distance graphs constructed from seismic-refraction data obtained at beach station 49 
Figdre 8. Time-distance graphs constructed from seismic-reafction data obtained at beach station 14...

9. Time-distance graphs constructed from seismic-refraction data obtained at beach stations 27 and 45 .

Page

B20

10. Profile of continuous beach seismic-refraction line relating time-distance curves to bedrock topography.

11. Tundra-survey map, showing location of tundra seismic line and USSR\&M drill-hole lines

12. Profile of tundra seismic-refraction line relating time-distance curves to bedrock topography

13. Idealized cross sections and stratigraphic column of Nome beach and tundra seismic-investigations areas 


\title{
CONTRIBUTIONS TO ECONOMIC GEOLOGY
}

\section{A PORTABLE REFRACTION SEISMOGRAPH SURVEY OF GOLD PLACER AREAS NEAR NOME, ALASKA}

\author{
By H. Gary Greene
}

\begin{abstract}
During the summer of 1967 a seismic-refraction study was made of the beach and tundra gold-placer areas near Nome, Alaska; a small lightweight portable seismograph system was used. Geophone configuration and type of sound source for: this investigation were determined during a preliminary experimental survey.

Results of the beach survey indicated that internal stratigraphy of the overburden could be interpreted and that seismic velocities could be assigned to the different units. $\Lambda$ very low velocity dry to damp layer of Holocene sands covering most of the beach showed seismic velocities of 500 to 2,400 fps (feet per second). Low-velocity layers included in the overburden, which were especially conspicuous near river mouths, exhibited velocities of 2,000 fps to 3,400 fps. Below the very low velocity layer, a poorly consolidated Sangamon nearshore or estuarine silt, clay, and sand layer gave velocities of 4,000 fps to 6,000 fps. Beneath the estuarine material is an Illinoian till that has a velocity of 9,200 to 13,200 fps. Bedrock was well defined in all seismograms and exhibited velocities from 14,000 fps to 18,500 fps.

Inasmuch as the beach study was successful, a short experimental seismic line was completed inland to determine the usefulness of a portable refraction seismograph in permafrost areas near Nome. The basic problems in permafrost areas are the high seismic velocities in the overburden, due to the increase in elastic modulus resulting from the ground being frozen, and the acoustical absorption and variable thickness of the overlying tundra. The increase in sediment velocity recluces the possibility of a good velocity contrast at the bedrock-overburden interface, and the organic material of the tundra absorbs returning seismic energy. These problems were reduced by setting off the seismic explosion on the permafrost surface, and by placing the geophones in the thaw zone of silt beneath the spongelike matter of the tundra.

A basement contour map of the beach was constructed from depth data obtained along the beach with the refraction seismograph, from offshore seismicreflection data, and from onshore drill-hole information. Several buried channels
\end{abstract}


were identified and may be sites of possible gold placer deposits. A bedrock cross section was constructed, showing that beneath the tundra the bedrock surface dips under Dry Creek from both sides, and a bedrock contour map was drawn from refraction seismograph data and drill-hole information. Results of the tundra survey illustrate the feasibility of the portable seismograph as a tool for placer prospecting in the Nome area.

\section{INTRODUCTION}

During the summer of 1967, fieldwork on the beaches of Nome, Alaska, was done as part of the U.S. Geological Survey's Heavy Metals Program on the Seward Peninsula. This was one of several independent studies, offshore and on the beach, of the sedimentary processes, the Pleistocene stratigraphy, and the gold resources of the Nome area. The studies of the beach included a seismic-refraction survey and $a$ heavy-mineral investigation. Results of the seismic-refraction survey only are given in this report.

Portable refraction seismographs have been used by soil engineers and engineering geologists for many years in studying overburden thickness and physical properties at construction sites for highways, dams, buildings, and other such installations. Also, the portable seismograph has been used in Alaska and California, as well as in other countries, such as South Africa, in surveys of placer deposits. However, no seismic-refraction investigation of the beaches of Nome, Alaska, had ever been attempted. Inasmuch as the seismic survey on the unfrozen beach was successful, a short experimental seismic line was completed inland to determine the usefulness of the portable refraction seisrnograph in areas of permafrost. The success of the Nome studies later led Tom E. Smith, of the U.S. Geological Survey, to investigate overburden thickness in another permafrost region with the use of the same seismograph. He obtained interpretable seismograms in his investigation of the Kougarok Gravel in the interior of Seward Peninsula (T. E. Smith, oral commun., 1968).

\section{OBJECTIVE}

The primary objective of the seismic-refraction survey of the beach and tundra areas near Nome, Alaska, was to determine the thickness of overburden and to distinguish the buried stream channels beneath the beach. A secondary, but significant, objective was to establish bedrock topography under the shoreline west of Nome, so that bedrock configuration determined offshore by marine seismic-reflection and drill-hole information could be correlated with known bedrock topography onshore. Because the portable seismograph has potential as a prospecting tool in investigating detrital deposits of heavy metals, the methods used in this study are given in some cletail. 


\section{LOCATION}

Areas of investigation are on the western half of the Seward Peninsula on the Nome coastal plain (fig. 1), which fronts on Norton Sound. The beach region under consideration extends from the mouth of the Snake River westward to the mouth of Penny River-a distance of about 10 miles. The experimental tundra line was located inland approximately $1 \frac{1}{2}$ miles northeast of the center of Nome, on Dry Creek (fig. 2).

\section{GEOLOGIC SETTING}

The Nome coastal plain is covered with Pliocene (?) and Pleistocene marine and glacial sand and gravel. Four main marine units are recognized and are locally known as Submarine Beach, Fourth Beach, Third Beach, and Second Beach, each representing different sea-level stands during late Pliocene (?) and Pleistocene time (Hopkins and others, 1960, p. 46). Submarine Beach, Second Beach, and Third Beach are separated by glacial drift of the Iron Creek (pre-Illinoian) and the Nome River (Illinoian) Glaciations. Covering the glacial drifts and the youngest marine sediments are outwash, alluvium, colluvium, windblown silt, and peat accumulated during Wisconsin and Holocene time (fig. 3). Beneath the sediments of the coastal plain and cropping

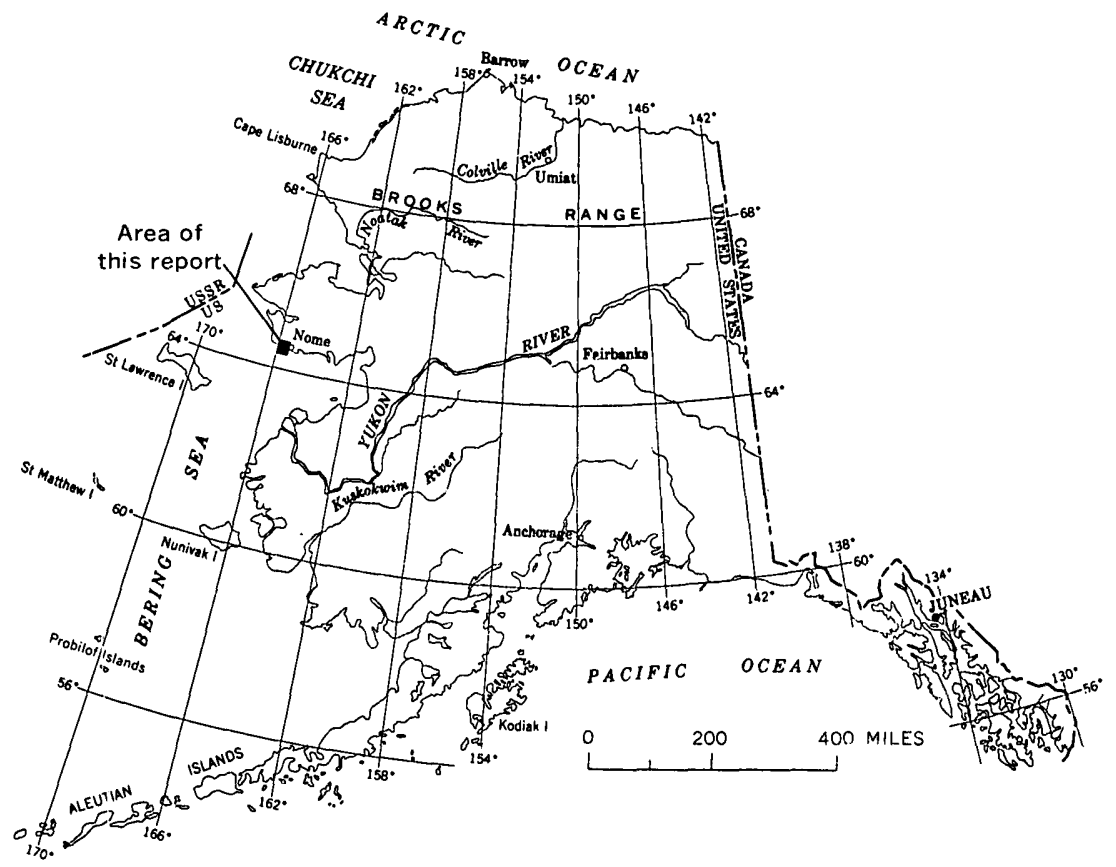

FraURe 1.-Index map of Alaiska, showing survey area. 


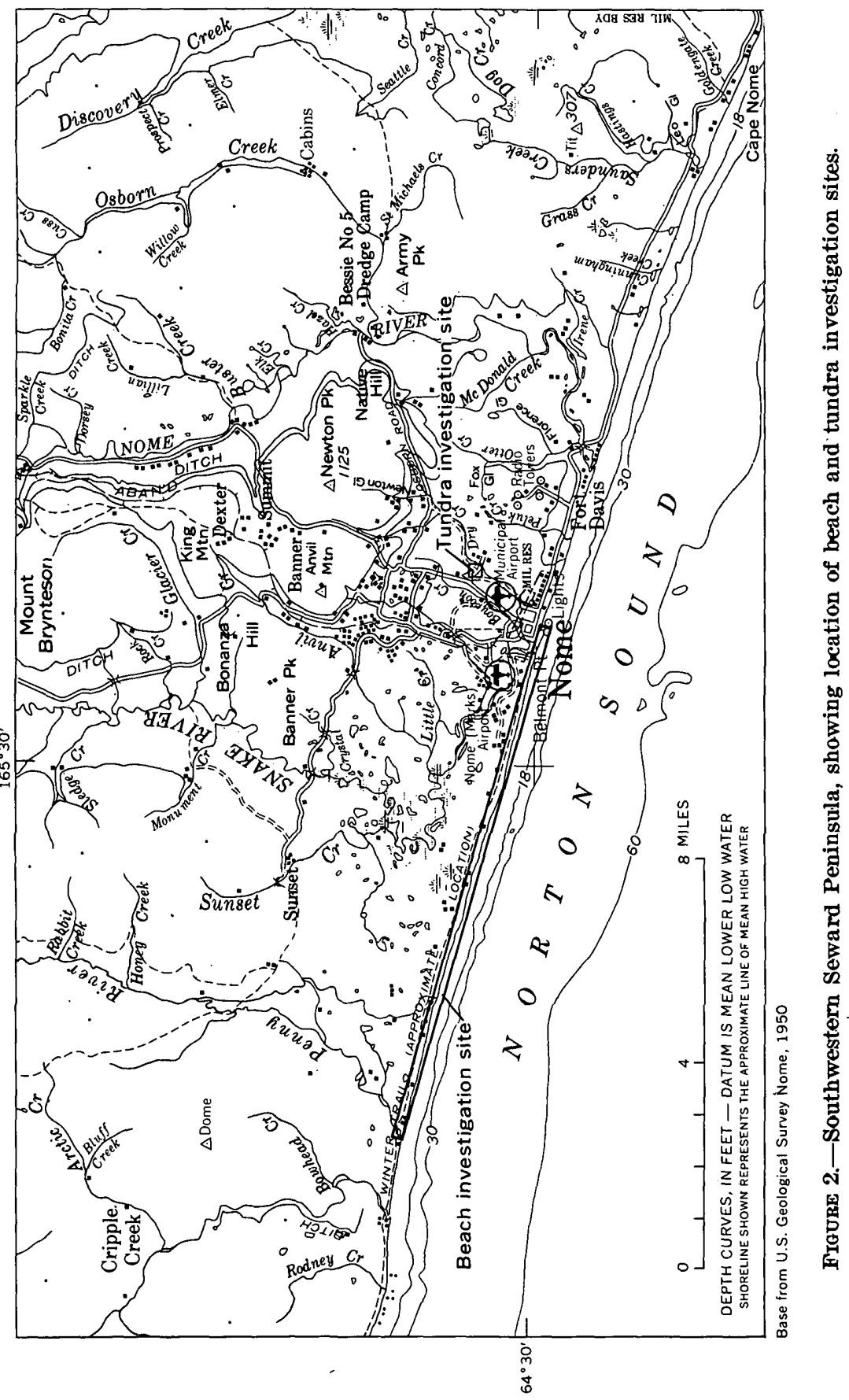


out behind the coastal plain is Paleozoic schist and limestone bedrock that is faulted in many places (Collier and others, 1908, p. 149). Hopkins $(1967$, p. 49-90) described the stratigraphy in greater detail, and the reader is referred to this source for the most recent interpretations.

Geology of Submarine Beach was projected to the modern beach and used in the interpretations of stratigraphy beneath the present beach. Submarine Beach consists of two strips (Inner and Outer) of marine sediments oriented parallel to the present coast near the lower course of the Snake River (fig. 3). The sediments consist of 1 to 3 feet of sand and pebbly sand resting on bedrock where bedrock is high, and on a shell-rich clay where bedrock is low; these sediments appear to represent nearshore deposits, rather than true beach deposits (Hopkins, 1967, p. 46). Geology of the present-day beach was summarized by Brooks (Brooks and others, 1901, p. 85-91) from his examination of mining pits on the beach in 1898. Brooks observed a blue clay bed found close to the tundra that sloped toward the sea and was referred to by the miners as a "false bedrock." About halfway down the beach (seaward), the clay bed was recognized beneath 5 to 7 feet of sand and gravel. Brooks could not trace the clay bed, or determine its thickness, along the entire length of the beach; even though seams of clay appeared at several different locations. Possible evidence of similar clay beneath the beach in several places was found during the seismic survey and was interpreted as an offshore shallow-water sediment deposited during Second Beach time. Also found were fine sands and coarse gravels containing a few thin lenses of clay immediately above the clay stratum.

In the vicinity of Dry Creek, a thin layer of Wisconsin peat, loess, and colluvium overlies the till and outwash of the Nome River Glaciation, which rest upon Paleozoic schist bedrock (Hopkins and others, 1960 , p. 48 ; fig. 3 ). At the location of the tundra seismic line, Dry Creek has cut through the Wisconsin material and down about 20 feet into the Nome River till and outwash. Although the creekbed contains boulders of schist, no bedrock outcrops were seen.

\section{PREVIOUS INVESTIGATIONS}

The well-known gold rush at Nome between 1898 and 1900 precipitated the early geological investigations of the area by the U.S. Geological Survey (Brooks and others, 1901; Collier and others, 1908; Moffit, 1913). Later investigations of the Nome coastal plain were undertaken by the United States Smelting, Refining \& Mining Co. (USSR\&M) and by the U.S. Geological Survey (MacNeil and others, 1943, p. 69-96; Hopkins and others, 1960).

374-544 O-70-2 


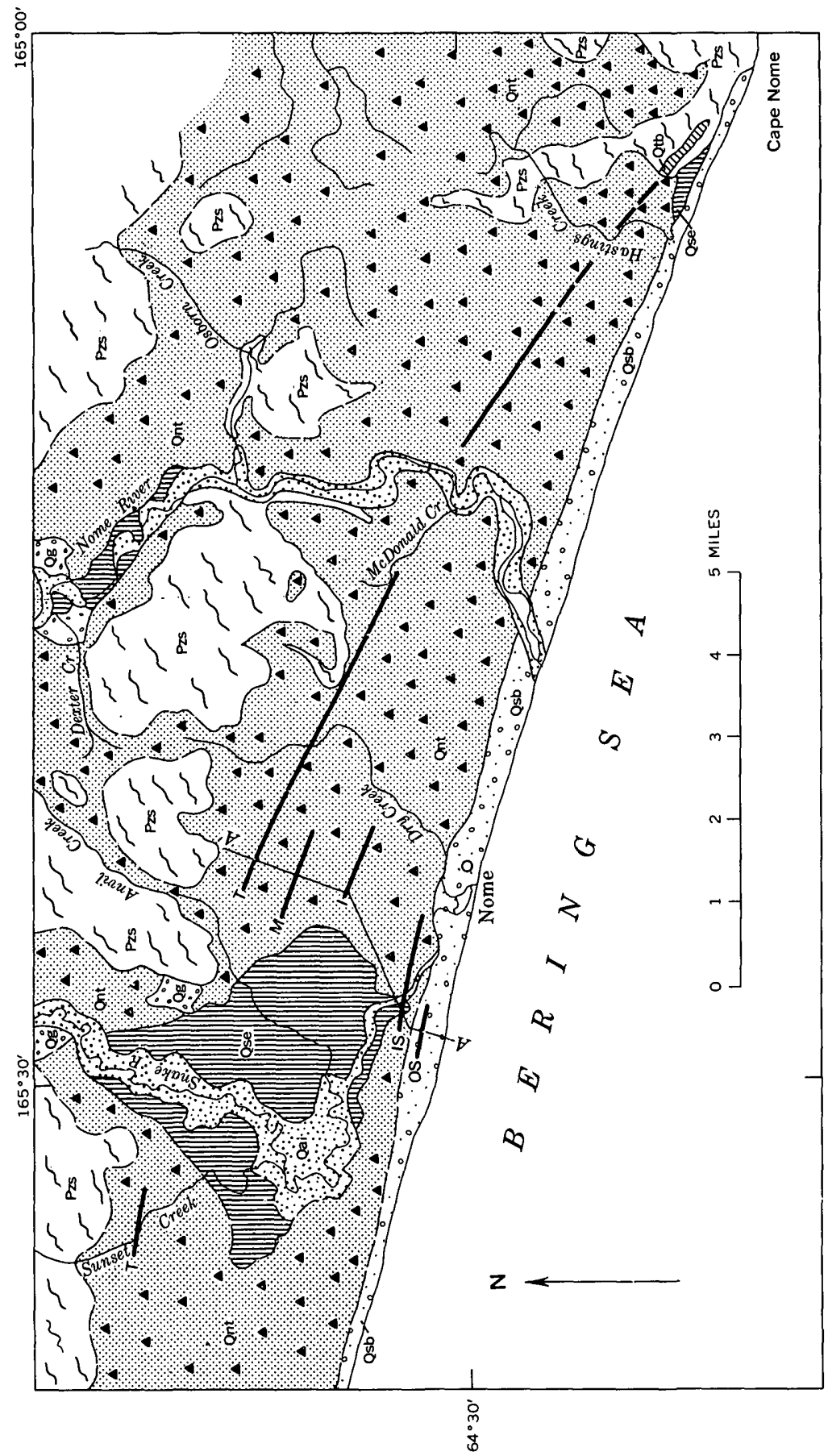



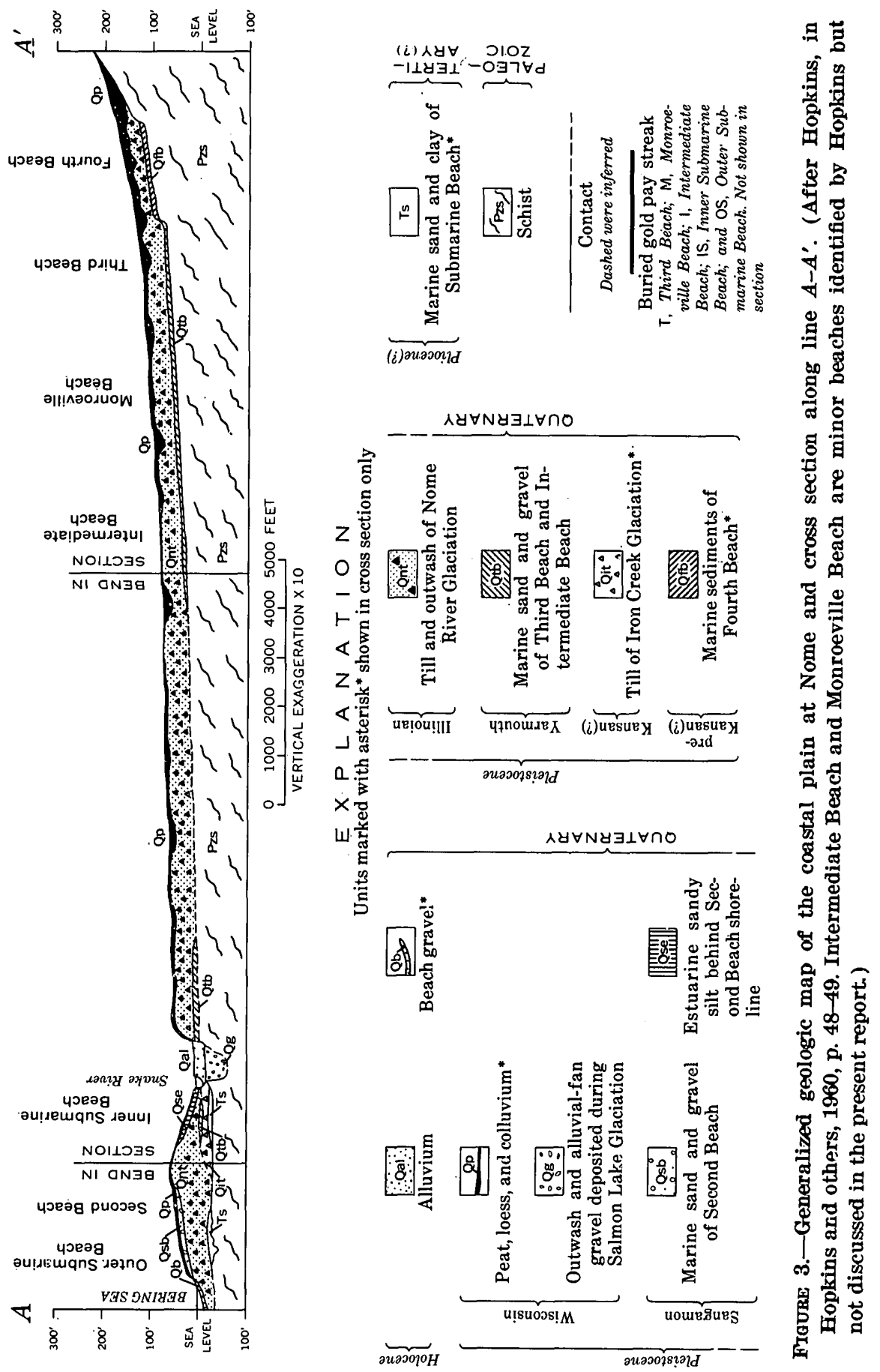
Beach placers of the Nome region extended along the shores of the Bering Sea from Cape Nome to Cape Rodney, a distance of 36 miles. Gold concentrations along the beach were found just above a false bedrock of silt, sand, and gravel; true bedrock was found at a depth of 10 to 100 feet beneath the beach (Collier and others, 1908, p. 151). "Although only the most primitive methods were employed, over a million dollars were taken out [of the beaches] in a period of about 2 months. During the height of the excitement, over 2,000 men were engaged in beach mining. Many of them made from $\$ 20$ to $\$ 100$ per day. By the end of the summer [1899], the richest spots on the beach were practically exhausted" (J. B. Metcalfe and Ralph Tuck, written commun., 1942). Today only very fine gold can be found in the beach sands. Gold worth more than $\$ 2$ million, figured at the 1900 gold price of $\$ 20.67$ per ounce, has been taken from the present beach (Metcalfe and Tuck, written commun., 1942; Collier and others, 1908, p. 151). At $\$ 20.67$ per ounce, this would be equivalent to approximately 100,000 ounces. An estimated 5 million ounces of gold has been taken from the entire Nome area (Arthur Daily, oral commun. to A. R. Tagg, 1968).

\section{ACKNOWLEDGMENTS}

This study was made under the supervision of David M. Hopkins; I was assisted in the field at various times by A. R. Tagg, Frank Wang, T. W. Richards, and R. K. Walsh. Carol L. Winegard assisted in computations and analysis of field data.

\section{EQUIPMENT AND PROCEDURES}

\section{EQUIPMENT}

The seismic records were obtained with an Electro-Tech Porta-Seis Refraction System (model ER-75-12), which is a self-contained, battery-operated, portable seismic-recording interval timer that resembles several other commercially available instruments. Permanent seismic records are produced on Polaroid $4 \times 5$ inch film; the records contain 12 data traces, one shot-break trace, and timing marks at 19-millisecond intervals. Accessory equipment included a 6,000-foot multiconductor geophone cable and 12 EVS-4 vertical-moving coil geophones with a frequency of $7.5 \mathrm{cps}$ (cycles per second). The sound source may be dynamite, blasting caps, or sledge hammer and steel striker plate, but explosives proved to be necessary near Nome.

The portable seismograph used is a lightweight system, weighing only 40 pounds, and may easily be carried by one person. At Nome, the equipment was transported by tracked vehicles and helicopter; however, the gear can be backpacked into poorly accessible regions. 
A limitation of the system is the nickel cadmium storage batteries, which need to be charged daily for efficient operation, and 120-volt 50- to 60-cps input for the battery charger must be available. However, other types of charging systems probably could be used.

\section{EXPERIMENTAL SURVEY}

Before undertaking the investigation of the beach and tundra areas, a preliminary experimental survey was made with the seismic equipment to determine the best sound source and geophone configuration to use. For shallow refraction work, the spread-length determination described by Griffiths is sufficient: "In refraction seismology the size of the shot is controlled mainly by the maximum range from shot to geophone, which must be at least twice the critical distance $X_{c}$ if the second branch of the time-distance graph is to be properly defined. The critical distance in turn depends on the depth to the refractor of interest" (Griffiths and King, 1965, p. 101).

During the experimental survey it was found that blasting caps fired at buried depths of 2 feet beneath the beach surface could not impart enough energy through the beach sands to give good signal response, even when as many as three caps were fired together. However, $1 / 8$ to $1 / 4$ pound $(1 / 4-1 / 2$ of a stick) of 60 percent ditching dynamite, detonated with a No. 6 DuPont instantaneous blasting cap, in holes 2 to 3 feet deep and 3 to 5 feet above the water table was found to be adequate along most of the beach. Figure 4 compares seismograms produced with blasting-cap and dynamite sound sources. On the tundra, dynamite was used exclusively. As in seismic-reflection work, the explosive charges were buried at suitable depths, discussed later.

Profile shooting is the most common technique used in refraction work, and this method was used throughout the investigation. The method requires that shot and detectors be laid out in a straight line with equal spacing between detectors (pl. 1, part $D$; fig. $11 C$ ). Distances between geophones and between the shot and the first geophone were established on the basis of time-distance plots made at several different beach locations during the trial period.

The length of the geophone spread is dependent on dip of, and the depth to, the lower horizon under investigation-in this study, bedrock-and seismic velocities within overburden and bedrock. As long as the spread length is large enough to determine the distance corresponding to the critical angle of refraction, good resolution of the bedrock and intermediate, shallower layers are obtainable. A general rule established at Nome was to keep the spread length greater than twice the inferred depth to bedrock. Also, the shot-to-first- 


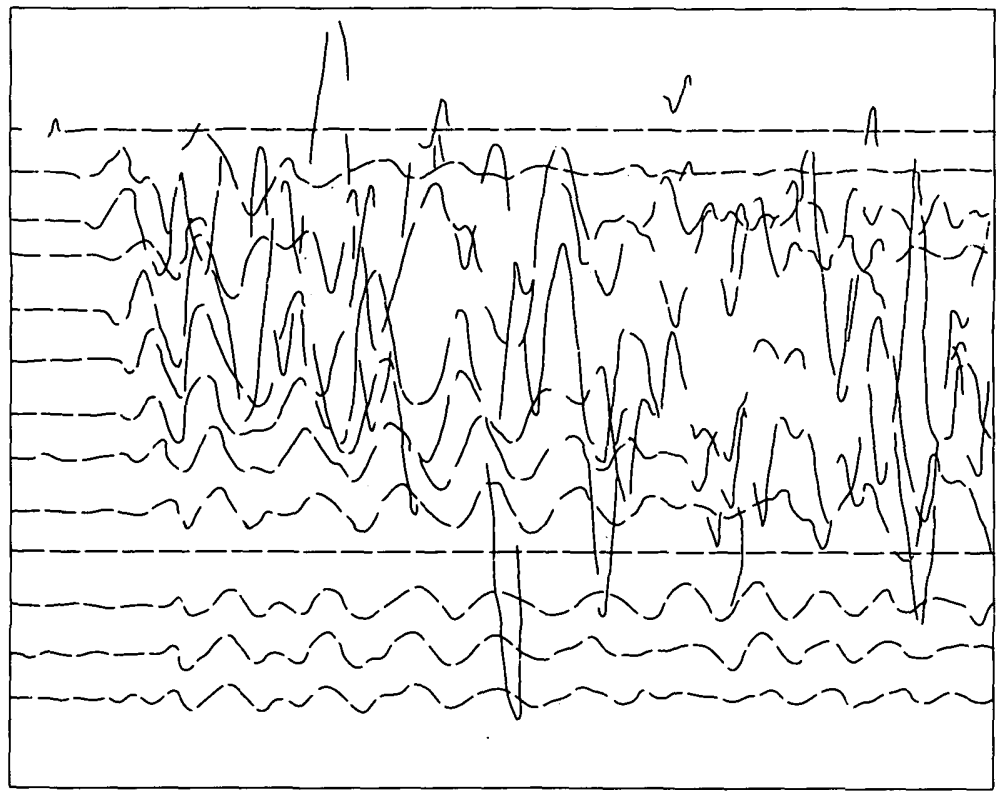

$A$

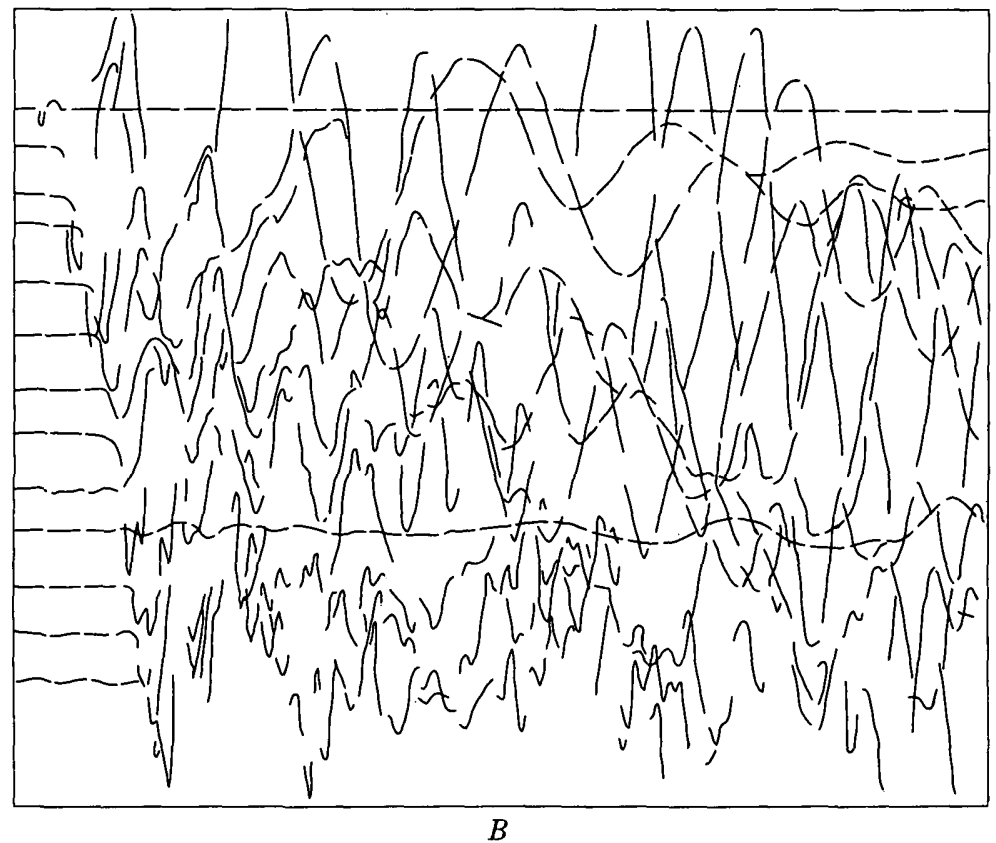

Frgure 4.-Seismograms obtained with blasting-cap $(A)$ and dynamite $(B)$ sound sources. 
detector distance was kept at about twice the critical-distance length of the expected shallowest refraction horizon, which was predicted to be between 10 and 30 feet. (See fig. 5 for illustration of critical distance.) A very low velocity surface layer, 5 to 12 feet thick, was disregarded during the fieldwork and neglected during the first analysis of the data. This layer is thought to consist mostly of dry sands on the beach and of peaty soil in the tundra. In some places, this layer probably absorbed so much energy that only the later phases of the signal were recorded, thus producing apparent velocities. Velocities of this surface layer should have been measured by using closely spaced geophones and greater charge sizes. Wherever first-arrival intercept times are very large, as was common for this area, a velocity study should be made. Probable variations in the degree of saturation at the top of the water table in some locations caused differences in arrival times and produced apparent velocities (David Barnes, written commun., 1968). To distinguish between true velocities and apparent velocities, overlapping spreads should be made, and this was done at several stations. (See fig. 10, in which station 33 is shown to overlap stations 103 and 104 of the continuous-profile beach survey.) Comparison with velocities obtained from the overlapping spreads and velocity measurements obtained during the offshore reflection investigation indicate that most of the seismic velocities mentioned in this report can be considered as true velocities. Preliminary shots indicated a bedrock depth of 20 to 60 feet beneath the beach, and 20 to 100 feet under the tundra. With the general rule kept in mind, spread lengths of 120 to 240 feet with geophone spacings of 10 to 20 feet were used experimentally on the beach, and spread lengths of 300 to 600 feet with geophone spacings of 25 to 50 feet were tried on the tundra. The distance of shot to first detector, known as shot offset, was kept at the same length as the geophone spacings and alined with the geophone spread. For best resolution, spread lengths of 192 feet with geophone spacings and shot offsets of 16 feet were found to be ideal for the beach; spread lengths of 300 feet with geophone spacings and shot offsets of 25 feet were suitable for the tundra survey. A detailed continuous-profile seismic line ${ }^{1}$ was run on a section of the beach to delineate a buried stream channel believed to lie 60 feet beneath the surface (pl. 1, parts $A$ and $C)$. Experiments before shooting the detailed line showed that a spread length of 300 feet with shot offsets and geophone spacings of 25 feet gave good bedrock definition. Alternative methods for shot and detector arrangements and a discussion of their respective advanta.ges and disadvantages were discussed by Dobrin (1960, p. 69-104).

\footnotetext{
1 The detalled line was designed to investigate the probable extension of a deep channel that had been discovered in a prospecting shaft about 1 mile inland (oral commun. from the late Mike Walsh to David M. Hopkins, 1961). The channel probably represents the preglacial course of the Snake River (D. M. Hopkins, oral commun., 1867).
} 
Signal to noise ratio must be considered when determining the best technique to use in a seismic investigation. Strong winds and heavy surf action, especially along beaches, produce seismic noise that may interfere with the identification of refracted seismic signals. Fortunately, during the time of the survey-the last 2 weeks of June and the month of July-no major storms occurred; consequently, most of the noise problems were eliminated. To improve the signal amplitude and poor signal response encountered during the preliminary survey, the geophones were placed at different depths below the beach surface. Geophones buried approximately 6 inches beneath the surface were found to give a signal response better than that from the geophones exposed on the surface.

Shooting a seismic survey across tundra and permafrost areas creates unique problems. The ground in tundra areas near Nome commonly remains frozen throughout the year at depths below 30 inches, and at the time of the tundra survey in July, the ground was found to be frozen 18 inches below the surface. It was feared that the increase in modulus of elasticity of the overburden caused by permafrost would increase the seismic velocity of the overburden so much that a good velocity contrast might not be obtained between overburden and bedrock. If this condition were to exist, seismic methods would not define changes in lithology. However, a vertical velocity contrast did exist in the area of the tundra survey, and the bedrock interface was definible. Most tundra areas are mantled by mosses and other acoustical absorbing organic matter; these act as an acoustical sponge which prevents the returning signals from being recovered. To eliminate this problem, geophones were placed in the thaw zone, in silt below the organic matter, and several inches above the permafrost surface. The signal amplitude was found to be equivalent to, or greater than, that obtained in the beach sands.

During the experimental period it was established that a person with little or no experience in operating a portable refraction seismograph could, within a few days, become proficient in obtaining good seismic records. However, general background in the use and handling of explosives is desirable.

\section{PROCEDURES}

The field techniques used in the Nome beach study involved two men (a shooter-observer and his helper) for rapid, efficient operation. Duties for the shooter-observer entailed digging and loading the shothole and readying the amplifier and recording oscillograph. Duties for the helper consisted of laying out the geophone cable, clipping geophones to the cable, and plugging the cable into the seismic ampli- 
fier. Upon completion of preparation, the shooter-observer detonated the charge to obtain a seismogram. Although it is easier and faster to operate the portable seismograph with two men, one man can do the job.

For the overall exploratory beach inveśtigation, a 192-foot spread length with a 16-foot geophone spacing was used, and all geophones were buried approximately 6 inches beneath the beach surface. Also employed was a $1 / 8$ - to $1 / 4$-pound dynamite sound source buried in a 3 -foot-deep hole in wet sand, about 2 to 5 feet above the water table, and offset 16 feet from the first geophone in line with the spread (pl. 1 , part $D$ ). For a continuous-profile beach line near the ancestral Snake River (pl. 1, parts $A$ and $C$ ), a 300-foot spread length with a 25-foot geophone spacing and shot offset (pl. 1, part $E$ ) was used, and the sound source was the same as for the overall exploratory beach study. By placing all geophones at equal elevations, terrain and elevation corrections were avoided. On the tundra, a 300-foot spread length with a 25-foot geophone spacing was used with all geophones positioned in the thaw zone just beneath the organic matter of the tundra. The best sound source was a 1/4- to 1/2-pound charge of dynamite buried about 2 feet beneath the tundra surface, on the permafrost, and offset 25 feet from the first geophone, in line with the spread (fig. $11 C$ ).

Seismic beach stations were generally located approximately half a mile apart (pl. 1, part $A$ ). Once a station was established and occupied, a marker was erected and later located accurately by Raydist positioning equipment mounted in a helicopter. The geophone cable was first laid out in a line parallel to the coastline. After obtaining the initial seismogram, a reverse shot was made, fired at the opposite end of the spread to aid determination of dip of the bedrock surface. On the continuous-profile beach stations, the reverse shot made for a previous spread was used as the shot point for a following line, making the survey continuous. Wherever the beach was wider than 200 feet (and it was at five stations), a line was shot perpendicular to the coastline to better delineate bedrock topography.

The tundra seismic line was oriented by a Brunton traverse and extended from Dry Creek Road 1,200 feet S. $40^{\circ}$ E. across Dry Creek; it consisted of four sections (fig. 11A). Elevation changes for this line were determined with a hand level. This survey was continuous, employing the same procedures used for the continuous-profile beach line with the last shot of a spread used as the shot point for the following spread.

Procedures for operating the seismograph were simple, and once a routine was established, the production of seismograms progressed rapidly. Because the seismograph used at Nome utilizes a pendulum 
for sweeping the galvanometer traces across the record, the instrument had to be level at all times. Therefore, at each station the recording oscillograph was placed on stable soil and carefully leveled. The geophone cable was connected to the instrument, and the continuity and ground leakage of each geophone were checked individually. After the charge was loaded and buried, the firing line was attached to the blaster connection on the instrument. The film packet was placed in the film holder and readied for exposure, and the pendulum was cocked and then released to fire the shot, thereby obtaining a seismogram.

\section{INTERPRETATION OF SEISMOGRAMS}

The object of refraction seismology "is to build up a time-distance graph with adaquate number of points on the branches corresponding to all refractors of interest * * *." (Griffiths and King, 1965, p. 121). Interpretation of refraction seismograms consists of picking, correcting, and plotting on time-distance graphs all first-arrival times. From. time-distance graphs, seismic velocities can be calculated, and depth determinations can be made.

\section{THEORY}

Recovery of refracted and reflected sound waves produced by controlled seismic explosions usually produces a seismic record indicating one or more events that are caused by the change in velocity of the wave front. Seismic energy is represented by elastic waves, and abrupt changes in the elastic properties through which the wave is propagated will cause the wave to be refracted or bent. The amount of bending is dependent upon Snell's Law-that is, sine of the angle of incidence is equal to sine of the angle of refraction. Another way of representing this law is by the following equation:

where

$\stackrel{\operatorname{Sin} i}{\operatorname{Sin} r}=\frac{V_{1}}{V_{2}}$

$i=$ angle of incidence,

$r=$ angle of refraction,

$V_{1}=$ velocity of transmission of elastic wave in incidence medium, and

$V_{2}=$ velocity of transmission of elastic wave in refraction medium.

A major concept in refraction work is that of the critical angle. Where the angle of refraction equals $90^{\circ}$, the sine of the angle of incidence equals $V_{1} / V_{2}$. Here the incident ray strikes the interface at the critical angle, and the refracted wave travels parallel to the interface. $A$ refracted wave acts as a first arrival when the time required for it 
to travel from the source through the refraction layer to the detector is equal to or greater than, the time required for the direct wave to travel from the source to the detector. Distance along the ground surface from the source to that point where the refracted wave and the direct wave meet is called the critical distance, $X_{c}$, and, as shown later, is an important function in calculating depth of the refraction horizon (fig. 5). The path that first-arrival waves take is dependent upon the depth to the reference interface and the distance between the first geophone and the source.

When first-arrival times are plotted on a time-distance graph, a break in the slope of the time-distance curve will occur where the time taken for both direct and refracted waves to travel from source to detector are the same (fig. 5). Velocities are obtained from the slope rate on the time-distance curve.

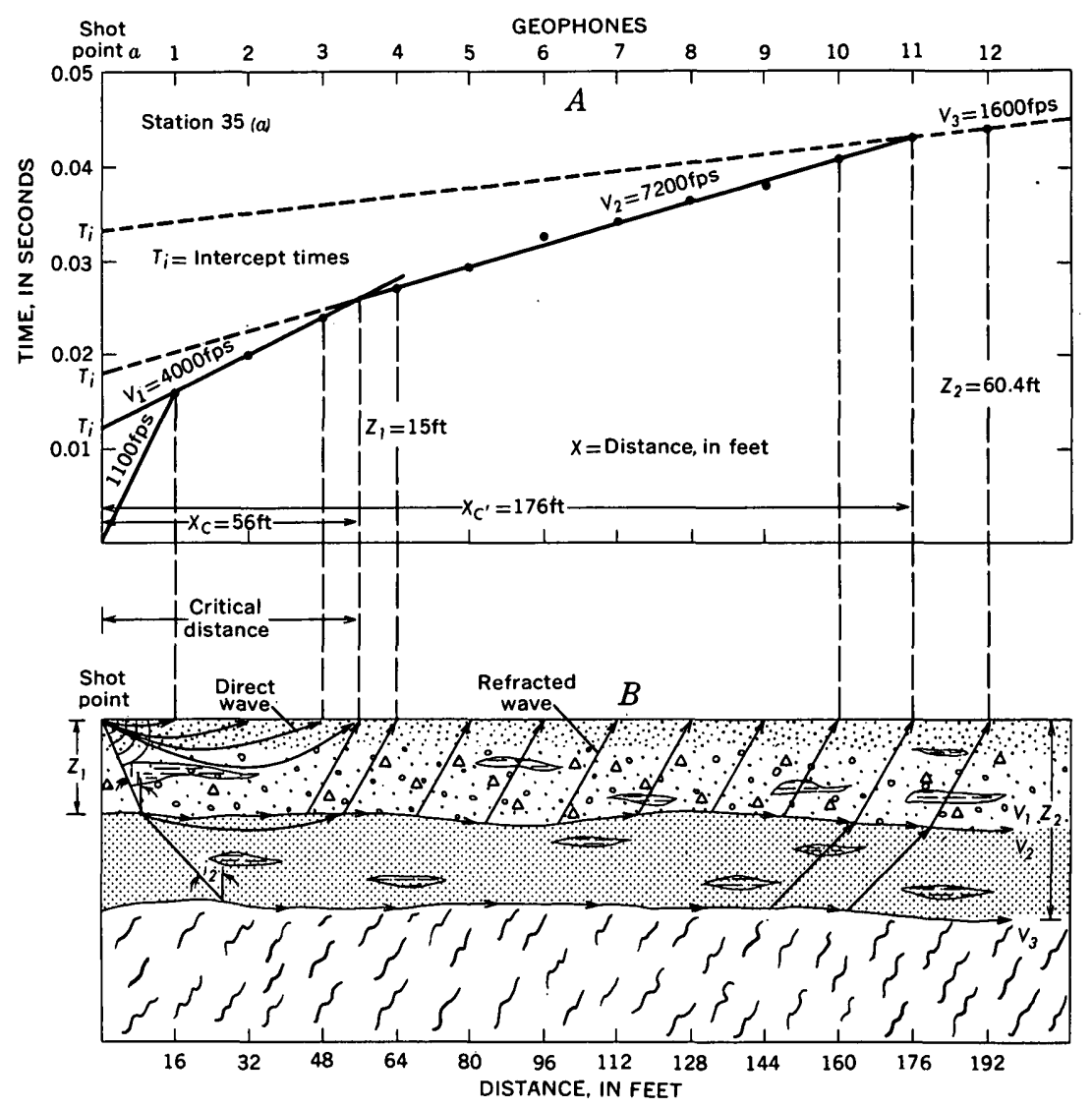

Figure 5.-Time-distance graph $(A)$ and schematic representation of refraction of seismic energy at three acoustical interfaces $(B)$. To simplify the diagram, the upper low-velocity layer has been ignored. 


\section{PLOTTING OF DATA}

First-arrival times were picked from seismograms by locating points where the galvanometer traces first departed from a straight line drawn parallel to the first part of the trace (fig. $6 \mathrm{~A}$ ). Traveltimes were assigned to these points by comparing their positions with the timing marks (time scale). The first-arrival times obtained were then corrected by applying the difference in time between the shot break and the zero timing mark. A transparent timing plotter that could be laid over the seismogram and adjusted so that the corrected times could be read directly from the seismic record was developed.

Once the first-arrival times were determined, they were plotted on a time-distance graph (fig. $6 B$ ). By using the two equations:

where

$$
\begin{gathered}
\text { Velocity }=\text { Time } / \text { Distance, } \\
\qquad Z=\frac{X_{c}}{2} \sqrt{\frac{V_{1}-V_{2}}{V_{1}+V_{2}}},
\end{gathered}
$$

$Z=$ depth to acoustic interface,

$X_{c}=$ critical distance, and

$V_{1}, V_{2}=$ velocities of first and second layers, respectively,

seismic velocities for each layer and depth to each acoustical interface shown on the seismograms were calculated from information developed on the time-distance graph. A third equation, utilizing intercept times, ${ }^{2}$ was used to check depth calculated by the critical distance method. This equation is given below:

where

$$
Z=\frac{T_{i}}{2} \frac{V_{1} V_{0}}{\sqrt{V_{1}^{2}-V_{0}^{2}}},
$$

$Z=$ depth to acoustic interface,

$T_{i}=$ intercept time, and

$V_{0}, V_{1}=$ velocity of first and second layers, respectively.

The depth information obtained by both the intercept-time and critical-distance methods were used to construct contour maps and cross sections of the investigation areas.

There are four standard interpretation procedures used by refraction seismologists: (1) critical-distance formulas, (2) time-intercept formulas, (3) apparent-velocities-of-sloping-layers formulas, and (4) delay-time formulas. The choice of an interpretation technique depends on local conditions and the interpreter's judgment and experi-

2 The intercept of the time-distance line, or the time axis, is the intercept time. (See flg. 5.) 


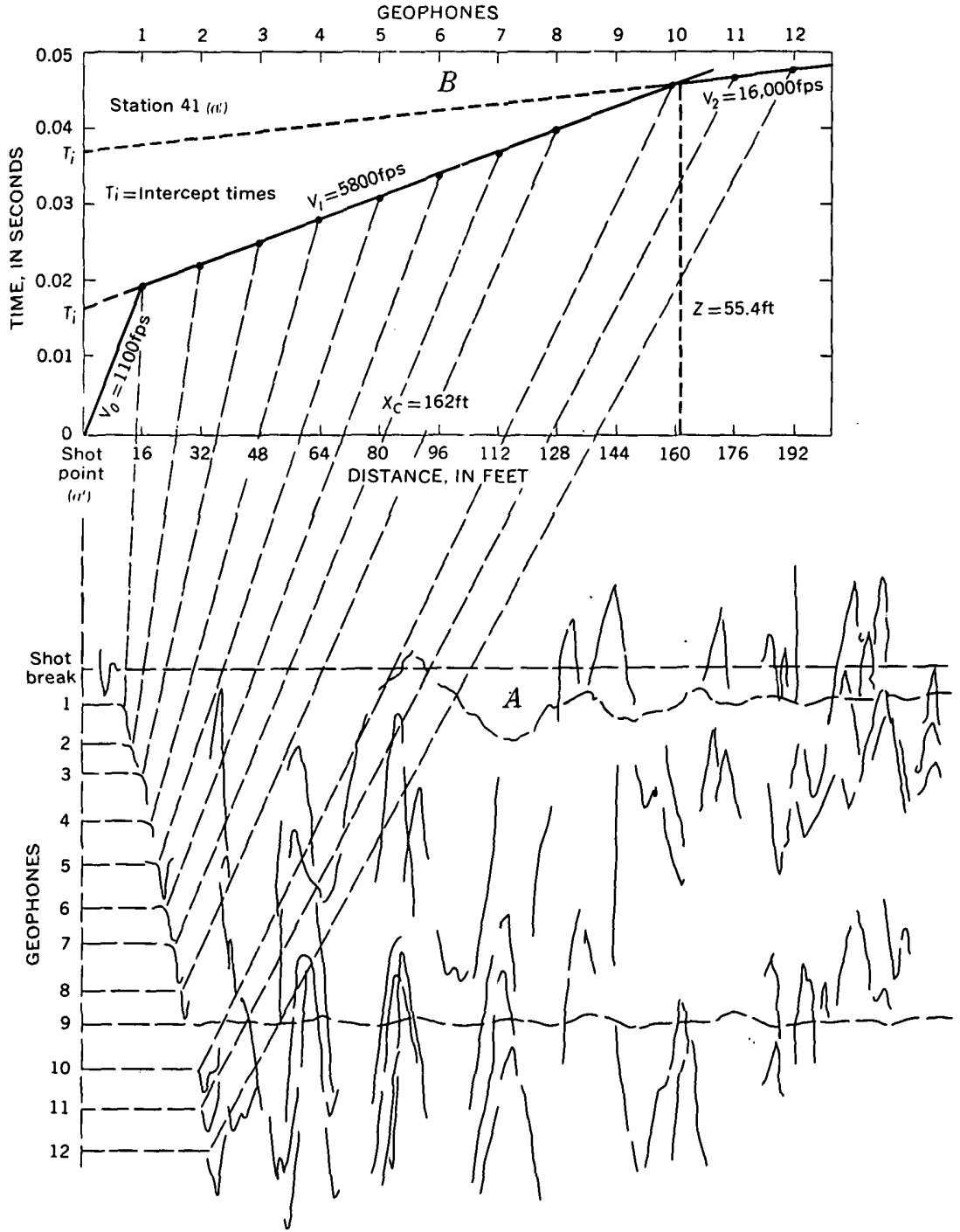

Froure 6.-Refraction seismogram $(A)$, showing how first-arrival times are picked and plotted on a time-distance graph $(B)$. Note result of dead galvanometer on data-trace 9 .

ence (David Barnes, written commun., 1968). In this survey, the first two techniques were used, but the more complex dipping-beds method probably should have been used where sloping layers were found, and might have changed the interpretation. However, where dipping interfaces were inclined at great angles, the depths and velocity of those interfaces were checked by using the dipping-beds formula and found to show no appreciable variation in the interpretation. 
The following sources can be referred to for a more detailed discussion on refraction theory: Hodgson (1964) and Griffiths and King $(1965$, p. $66-135)$, for a clear and concise elementary discussion of refraction seismology; Dobrin (1960, p. 64-104), Nettleton (1952, p. 245-279), and Dix (1940), for a more technical and advanced approach to the subject.

\section{RESULTS}

Contour maps and cross sections of beach and tundra investigation areas were constructed from data obtained by the interpretation of seismograms and time-distance graphs and were correlated with offshore seismic-reflection data and onshore drill-hole information. Apparent velocities and depths of different refractors were calculated.

\section{BEACH PROFILE}

Seismic velocities.-Velocities observed in overburden were highly variable, reflecting differences in lithology within the stratigraphic unit. Sharp acoustical discontinuities in some seismograms clearly indicate that two to three velocity layers are present in the overburden, whereas a lack of discontinuities in other seismograms suggests the absence of any distinct interface within the overburden. All seismic records show the bedrock interface to be well defined.

A very low velocity surface layer extends across most of the beach area and has a velocity range of 500 to $2,400 \mathrm{fps}$ (feet per second) with a mean velocity of $1,300 \mathrm{fps}$ and a median of $1,500 \mathrm{fps}$. For the upper layer in the overburden (layer $\mathbf{A}$ ), calculated velocities ranged from $4,000 \mathrm{fps}$ to $6,000 \mathrm{fps}$ with a mean velocity of 4,800 fps and a median of $5,000 \mathrm{fps}$. Occasionally, a low seismic velocity was detected in layer A with a range of $2,000 \mathrm{fps}$ to $3,400 \mathrm{fps}$, and a mean and median of 2,700 fps. This low-velocity zone was especially conspicuous near the mouths of rivers, as shown in seismograms from beach station 49 along the river-mouth bar of the Snake River (pl. 1; fig. 7). The lower overburden layer (layer B) exhibited variation in velocities from $9,200 \mathrm{fps}$ to $13,200 \mathrm{fps}$ with a mean velocity of $11,700 \mathrm{fps}$ and a median of 12,000 fps. Where there were no indications of layering in the overburden, the time-distance graphs showed seismic velocity ranges of 5,000 fps to $10,400 \mathrm{fps}$ with a mean velocity of $7,800 \mathrm{fps}$ and median velocity of 8,200 fps. Figures 8 and 9 show time-distance graphs of areas where three velocity layers exist. For the acoustic basement, or bedrock, the velocities ranged from 14,000 fps to 18,500 fps with a mean of 16,200 fps and a median of $16,000 \mathrm{fps}$.

Depths.-Depths to different acoustical interfaces were calculated from the time-distance graphs and indicate an average depth of 6.5 feet to the base of the very low velocity surface layer, an average depth 

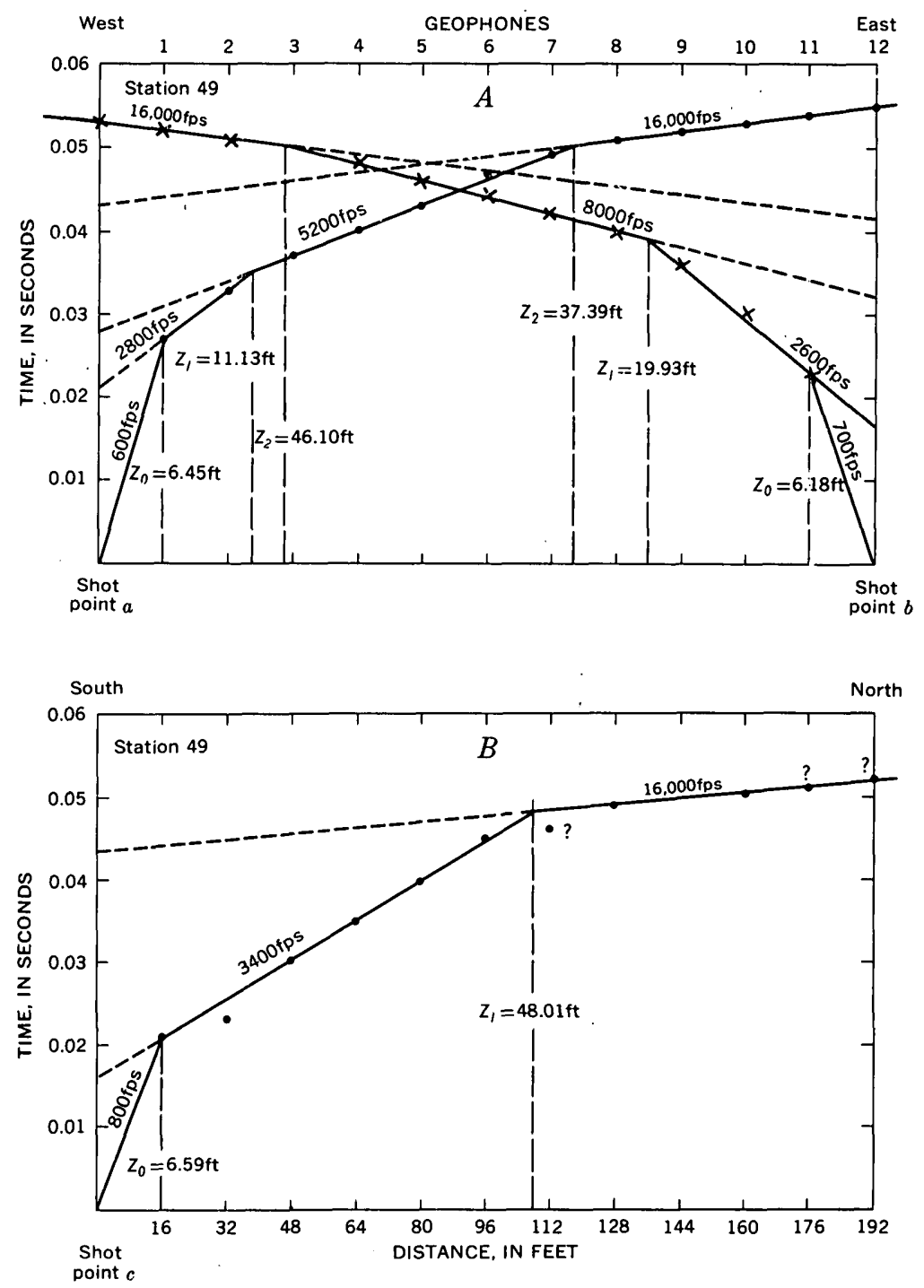

Frgure 7.-Time-distance graphs constructed from seismic-refraction data obtained at beach station 49 , showing four velocity layers with the lowest velocity layer characteristic of Holocene sediments that accumulate near river mouths. $A$, Time-distance curves from line shot parallel to coastline. $B$, Time-distauce curves from line shot perpendicular to coastline.

of 18.6 feet to the first interface (thickness of layer A), and an average depth to bedrock of 48.6 feet. Thickness of the surface layer ranges from 3.5 to 9.0 feet; thickness of the upper layer ranges from 0 to 27 feet; and thickness of the overall sediments overlying bedrock ranges from 34 to 80 feet. 

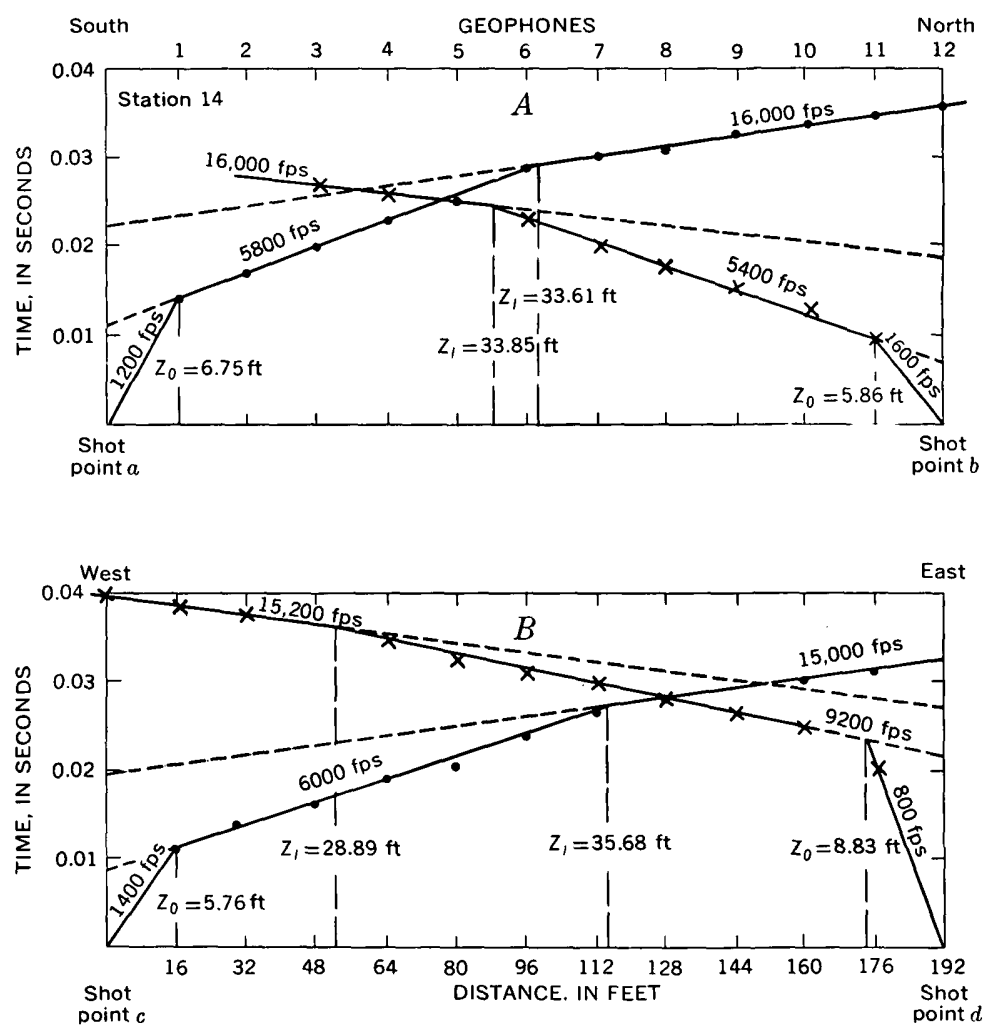

Frgure 8.-Time-distance graphs constructed from seismic-reflection data obtained at beach station 14, showing three velocity layers with the lowest velocity layer characteristic of Holocene sands and gravels. $A$, Time-distance curve from line shot perpendicular to coast. $B$, Timedistance curve from line shot parallel to coast.

The low-velocity surface layer and the first acoustical interface (surface of layer A) were not contoured but are shown in cross section (pl. 1, part $B$ ). There appears to be no relationship between the structure of layer $A$ and the bedrock surface.

Bedrock topography.-Depth results were used to construct a basement contour map and cross sections along the beach (pl.1). Contours drawn from the depth information showed a bedrock-surface topography that is undulating and correlatable with USSR\&M's bedrock contours inland, established from drill-hole data, and offshore bedrock contours established by seismic-reflection data (pl. 1, part $A$ ).

The following four major subsurface channels are shown on the contour map and cross section: Holocene Snake River channel, about onehalf mile west of the present outlet of the Snake River; offshore channel, approximately 4 miles west of the Snake River; ancestral 

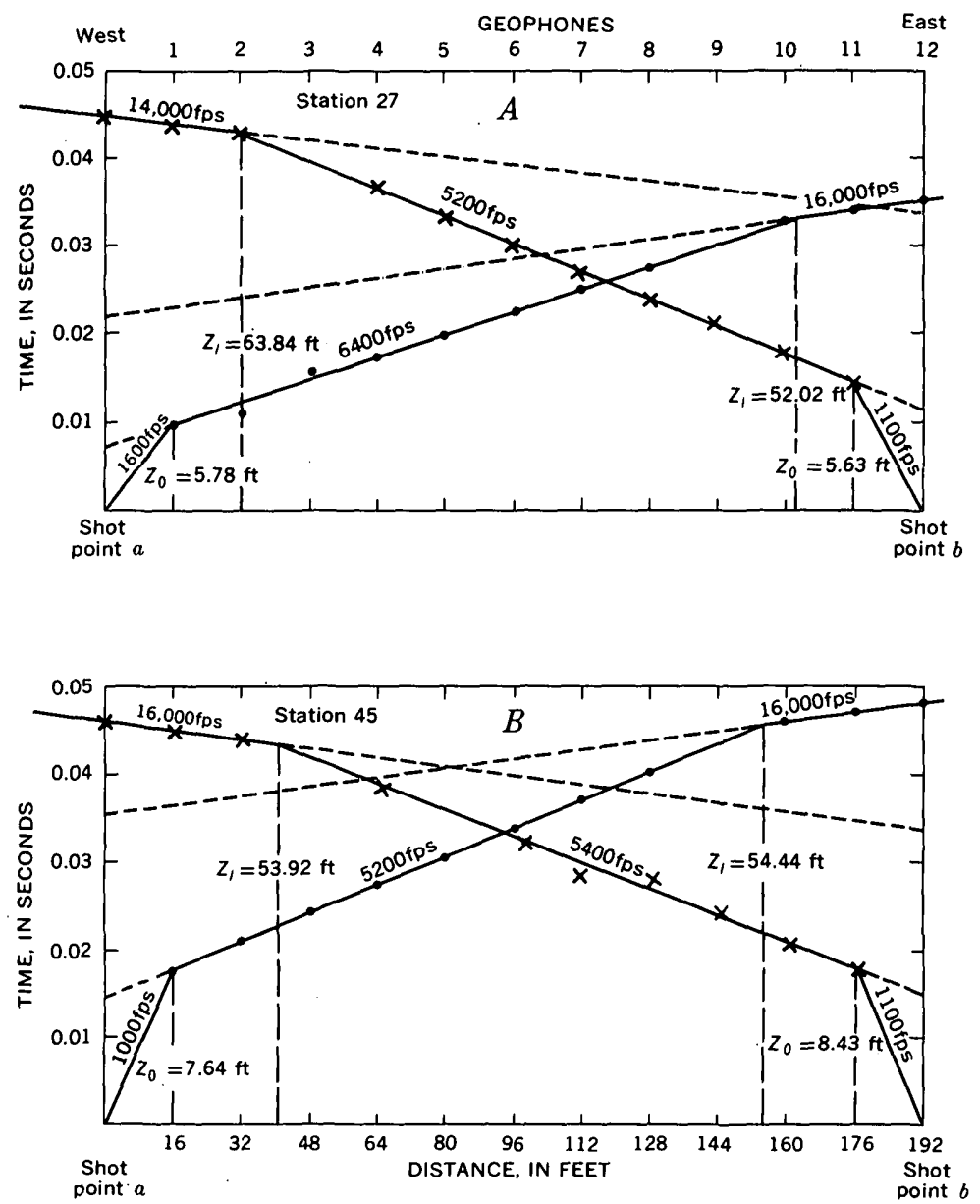

Fraure 9.-Time-distance graphs constructed from seismic-refraction data obtained at beach stations 27 and 45 , showing three velocity layers. $A$, Time-distance curves from line shot parallel to coast at station 27. $B$, Time-distance curve from line shot parallel to coast at station 45.

Snake River channel, about one-half mile west of offshore channel; and new channel, about 3 miles east of the Penny River (pl. 1, parts $A$ and $B$ ). The subsurface Snake River channels appear to aline fairly well with onshore contours; however, offshore channel does not correspond to any onshore data and has been constructed solely from offshore reflection data. New channel is not supported by either onshore- or offshore-depth information because of the lack of data and, therefore, may be newly discovered. Between beach stations 31 and 35, a detailed seismic line was run to outline the ancestral Snake River channel. A cross section made from this line shows an old river channel 
that consists of two well-incised tributaries and one broad riverbed cut into the bedrock surface (pl. 1, parts $B$ and $C$ ). Figure 10 shows time-distance curves of the continuous-profile line that can be explained by the bedrock topography shown in the section.
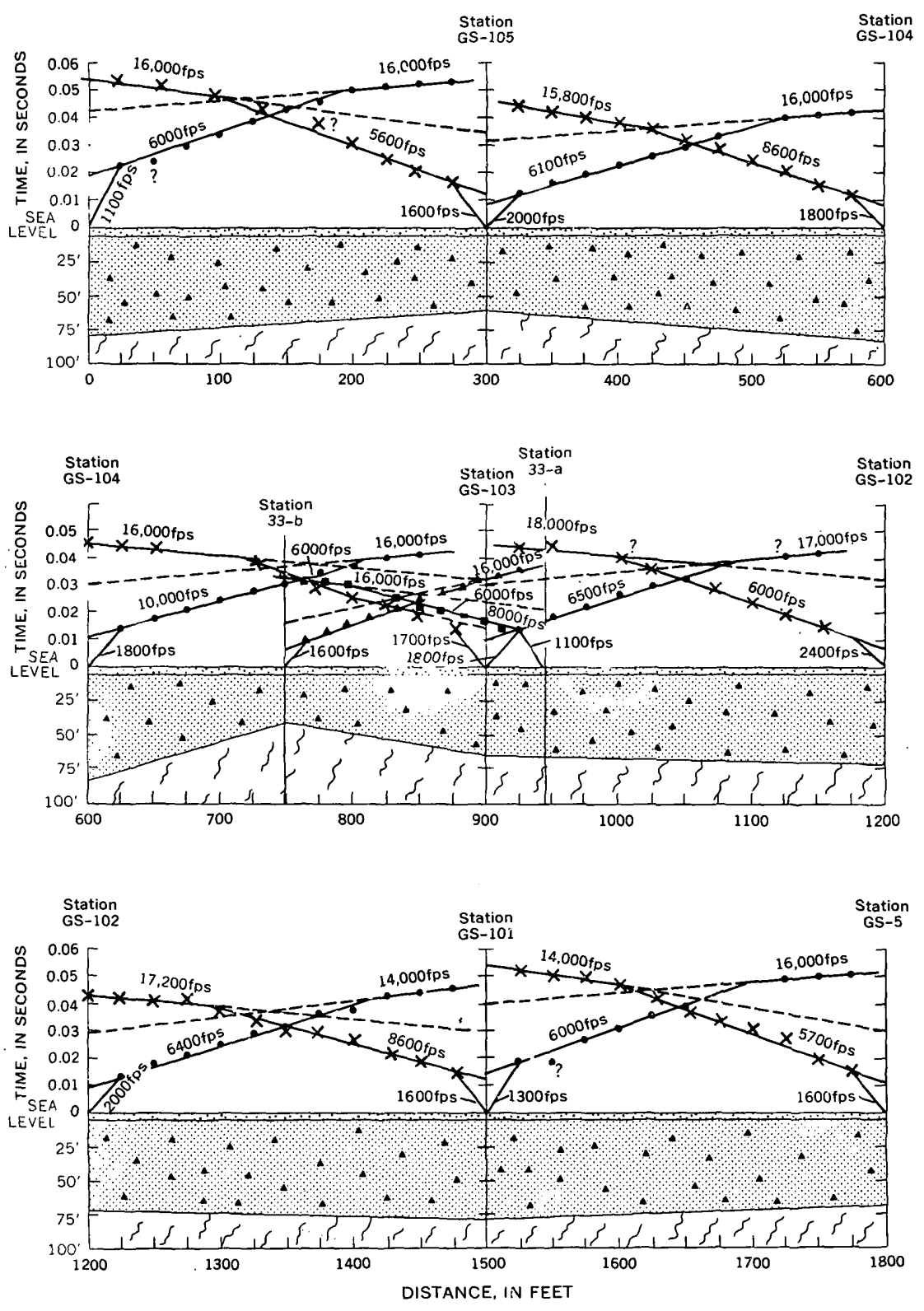

Figure 10.-Continuous-profile beach seismic-refraction 


\section{TUNDRA SURVEY}

Seismic velocities.-Time-distance plots constructed from seismograms obtained on the tundra defined a well-established bedrock interface with no other acoustic discontinuities in the overburden except
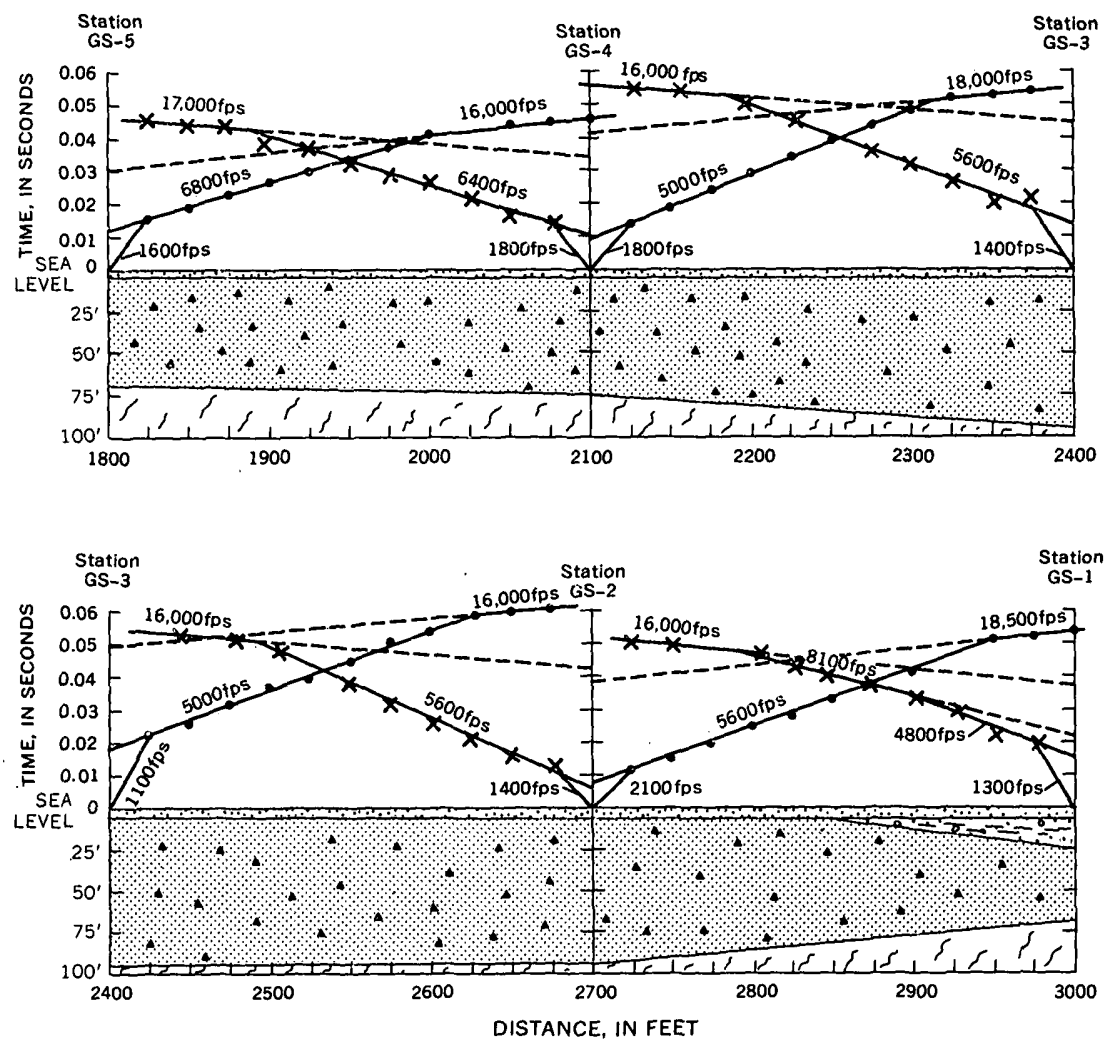

EXPLANATION
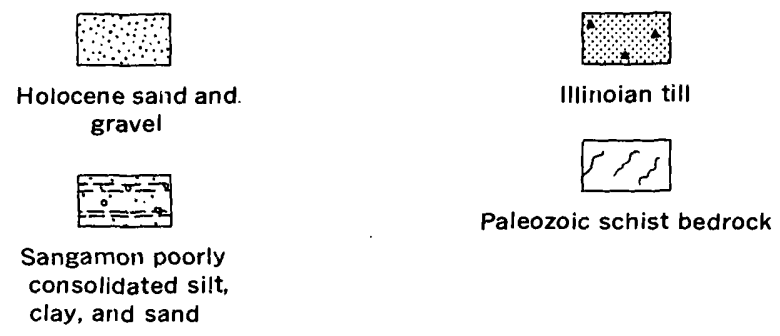

line relating time-distance curves to bedrock topography. 
for the surface very low velocity layer. Seismic velocities in the lowvelocity layer range from 600 to $2,300 \mathrm{fps}$ with a mean of $1,500 \mathrm{fps}$ and a median of 1,800 fps. Velocities in the overburden range from $5,200 \mathrm{fps}$ to $11,200 \mathrm{fps}$ with a mean velocity of $9,000 \mathrm{fps}$ and a median of $9,500 \mathrm{fps}$. The mean velocity for sediments overlying the bedrock here was $2,900 \mathrm{fps}$ greater than the mean velocity for sediments overlying bedrock on the beach. The higher velocities probably reflect the presence, beneath part of the line, of perennially frozen overburden. Velocity within the acoustical basement of the tundra ranges from $14,000 \mathrm{fps}$ to $18,500 \mathrm{fps}$ with a mean of $16,300 \mathrm{fps}$ and a median of $16,000 \mathrm{fps}$, which is nearly identical with the velocity of bedrock beneath the beach.

Depths.-Average depth to bedrock on the tundra was 48.8 feet, and sediment thickness varied from 38 to 60 feet. The low-velocity surface layer has an average thickness of 10 feet. Depth figures were used to construct a basement contour map and cross section (fig. 11), which show the bedrock surface dipping under Dry Creek from both sides. Figure 12 shows time-distance curves that can be explained by the stratigraphy shown in the section and suggests that a channel has been cut into the bedrock surface. Drill-hole data obtained by USSR\&M near the Dry Creek seismic line indicated an accuracy for the seismic data of \pm 4 feet for bedrock depth. Figure $11 B$ compares USSR\&M's drill-hole data with the cross section constructed from seismic information.

\section{DISCUSSION AND CONCLUSIONS}

\section{INTERPRETATION}

Interpretation of the Nome beach stratigraphy was made by comparing published geology with new observations, by studying drillhole information, and by correlating these studies with seismic data. Consideration of these factors led to the correlation of seismic velocities with interpreted stratigraphic units and produced insights for the reconstruction of geologic history.

Variation of seismic velocity within overburden partly reflects differences within the stratigraphic unit. For example, a poorly consolidated till may give lower velocities than a well-compacted till, bouldery till, or tillite; this type of condition most likely exists at Nome. In the overburden at Nome, where four velocity layers exist, it is believed that the lower velocities of layer $\mathbf{A}$ are caused by poorly consolidated post-till marine sand and silt of an offshore facies of Second Beach age, whereas higher velocities in layer B are the result of well-compacted, relatively fine grained till with boulders. The thick, extremely low velocity layers, such as those found near river mouths, 

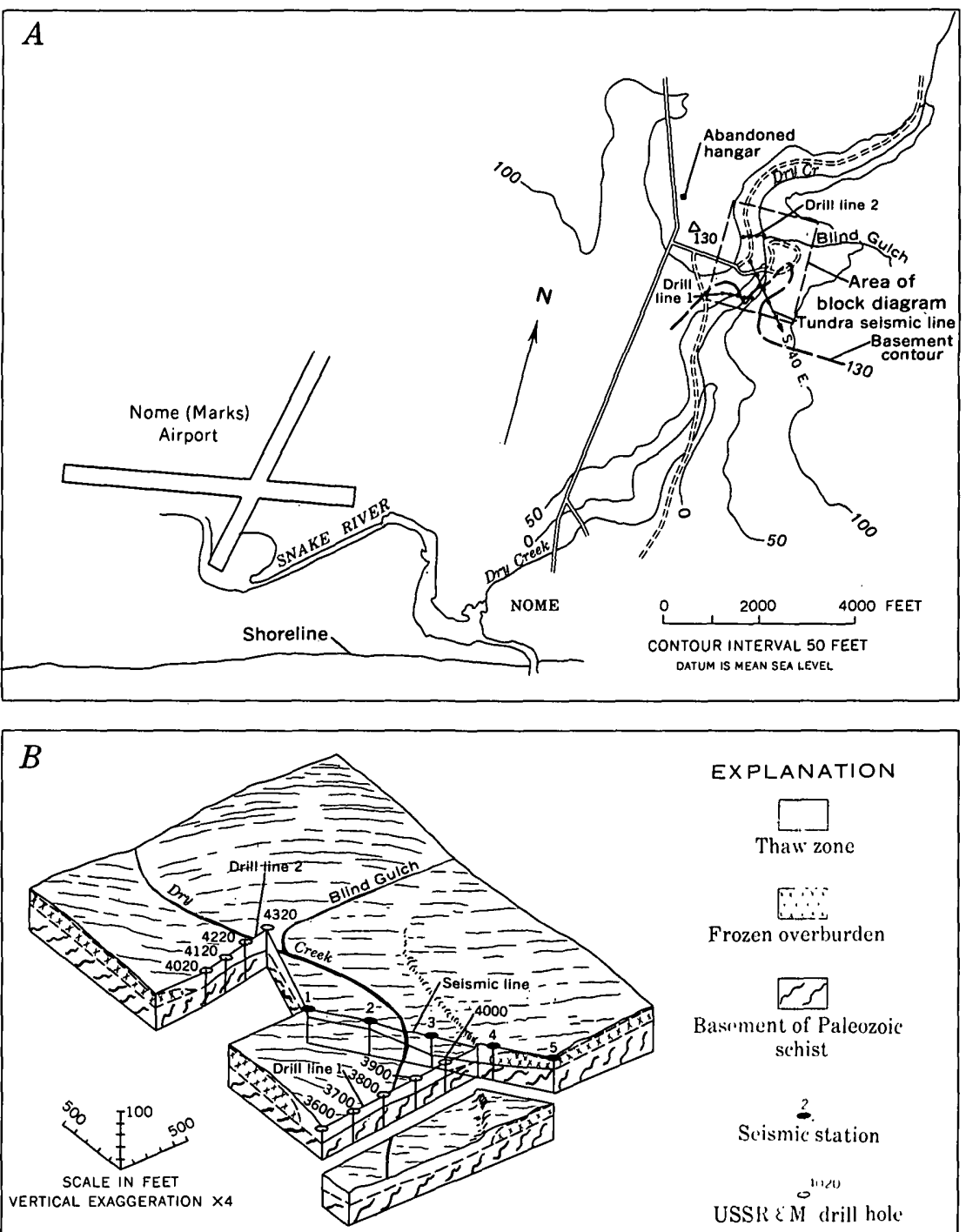

EXPLANATION
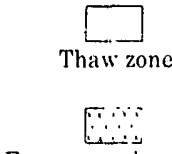

Frozen overburden

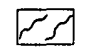

Basiment of Paleozoic schist

Scismic station

$0^{\prime \prime \prime 21)}$

USSR $C M$ drill hole

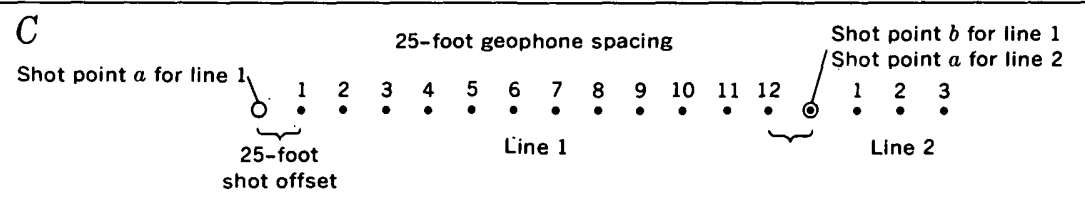

Figure 11.-Tundra-survey map, showing: $A$, Location of tundra seismic line and USSR\&M drill-hole lines. $B$, Relation between seismic line and drill-hole lines. Note correlation of basement from one line to the other. $C$, Plan view of geophone spread for tundra seismic line. Note that line is identical with line illustrated on plate 1 , part $E$. 

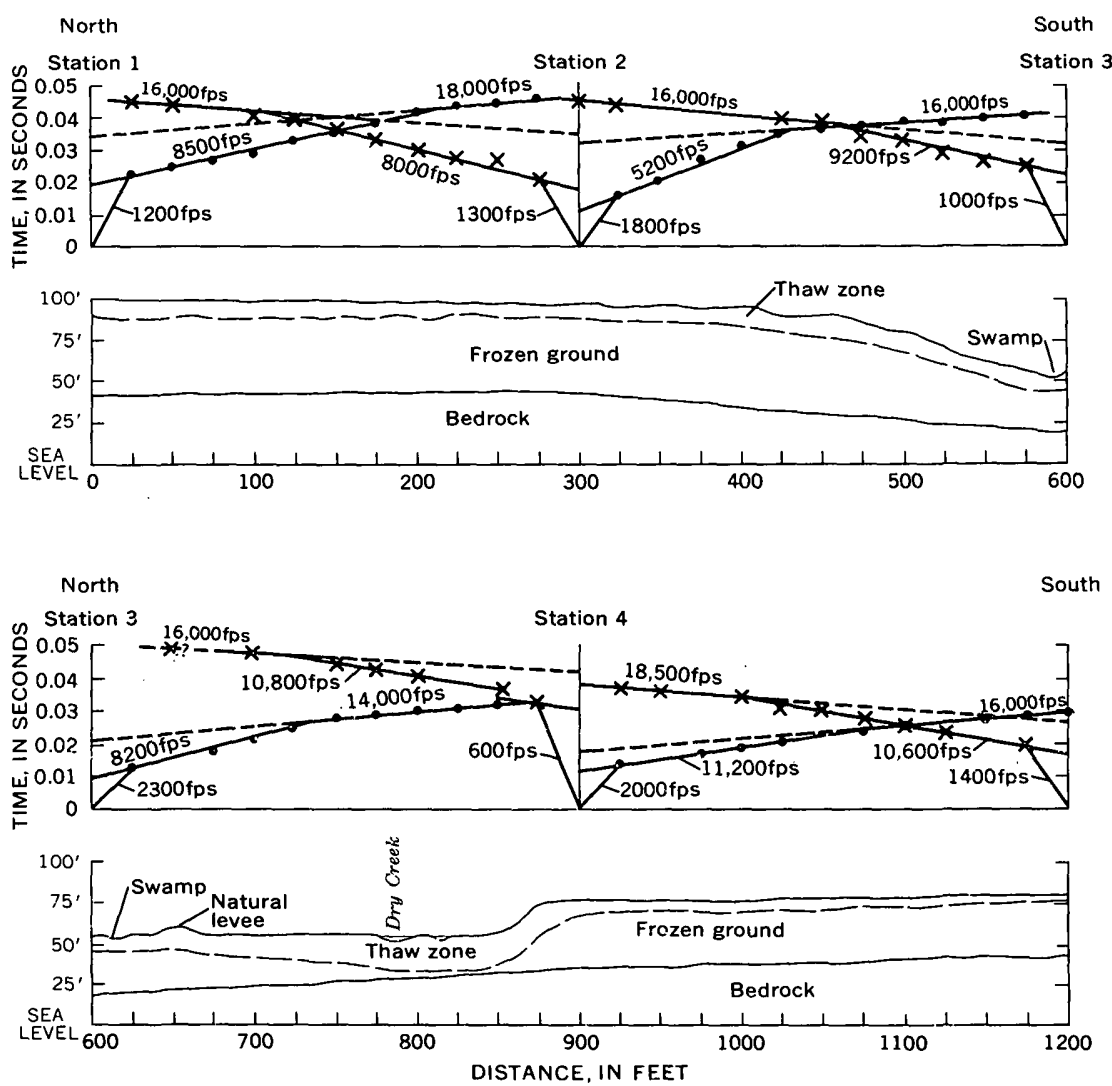

Figure 12.--Profile of tundra seismic-refraction line relating time-distance curves to bedrock topography.

are thought to be caused by the accumulation of unconsolidated Holocene beach sand and gravel. The very low velocity surface layer found covering most of the beach consists of dry to damp Holocene sand and gravel that is probably in transport. Variation of seismic velocities in this layer is possibly due to the difference in water saturation; several feet of dry sands above the wet sands found within the water table could produce the differential velocities. Where there is no velocity contrast in the overburden (only one acoustic layer present, not including the low-velocity surface layer), seismic velocities appear to represent an average velocity of both layer $A$ and layer $B$. This can occur when compaction of both layers is nearly the same, and boulders are lacking in the lower layer. At several places on the beach where this two-layer case existed, outcrops of Sangamon silt and sand that accumulated in shallow-water offshore or estuarine environment were observed (D. M. Hopkins, oral commun., 1967). Along the beach near station 35, a thin layer of beach sand and gravel covered sediment con- 
sisting of lagoonal deposits, peat, and iron oxidized gravels, possibly of Sangamon age. Unconsolidated beach sand and gravel included in layer A are characterized by velocities of $2,000 \mathrm{fps}$ to $3,400 \mathrm{fps}$, and the dry sand and gravel surface layer covering most of the beach are characterized by velocities of 500 to $2,400 \mathrm{fps}$. Drilling offshore and mining onshore show that bedrock underlying the beach and tundra consists of mica or graphite schist. A seismic velocity of 16,000 fps is typical for this type of rock.

Final interpretation with reference to the Nome geology led to the construction of a stratigraphic column and beach and tundra idealized stratigraphic cross section (fig. 13). The stratigraphic sections show a thin layer (0-15 ft) of unconsolidated beach sand and gravel overlying a silt and clay bed. Locally, the beach sand and gravel unit increases in thickness in the vicinity of river mouths. Beneath the beach material there are occasional layers of Sangamon outwash and estuarine deposits that vary in thickness. Underlying the Sangamon sediments is a relatively thick layer $(20-30 \mathrm{ft})$ of Illinoian till and outwash which overlies bedrock. Layer A consists of unconsolidated marine silty sands of Sangamon (Second Beach) age. Layer B consists of well-compacted Illinoian till and outwash. Bedrock is a mica or graphite schist. On the tundra the section consists of Wisconsin peat, loess, and colluvium overlying Illinoian till and outwash (Hopkins and others, 1960).

\section{POTENTIAL PLACER SITES}

Heavy-mineral deposits, including gold placers, have a tendency to be concentrated on bedrock, and, if stream deposited, they are likely to lie in bedrock channels. Beach deposits normally occur on flat bedrock surfaces seaward of a bedrock scarp. The need has long been felt for a tool to locate buried stream channels and subsurface structures that attract the accumulation of detrital gold and other heavy metals. An inexpensive and easy method to determine bedrock topography can be of great value in delimiting those areas likely to contain placers, and thus result in important economies in designing an exploratory placer-drilling program.

Results obtained with the portable refraction seismograph near Nome show that it is possible to acquire accurate data that can be used to determine locations and configurations of bedrock features that may be the sites of placer accumulations. The technique established for the Nome survey can also provide some information about internal stratigraphy of unconsolidated overburden. It has been shown that bedrock at Nome can be delimited in both permafrost and unfrozen areas.

Application of the seismic technique in the Nome area established 

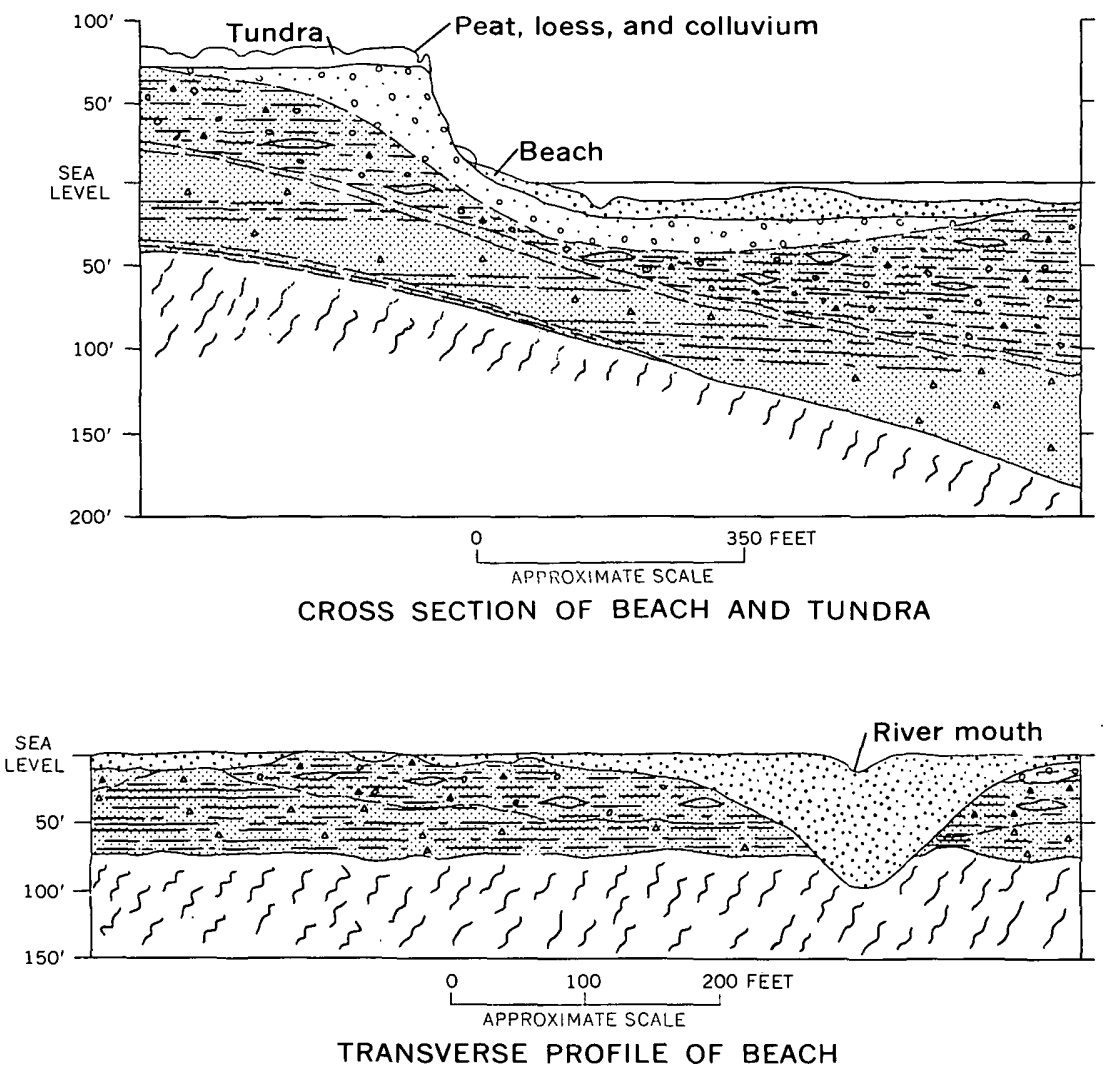

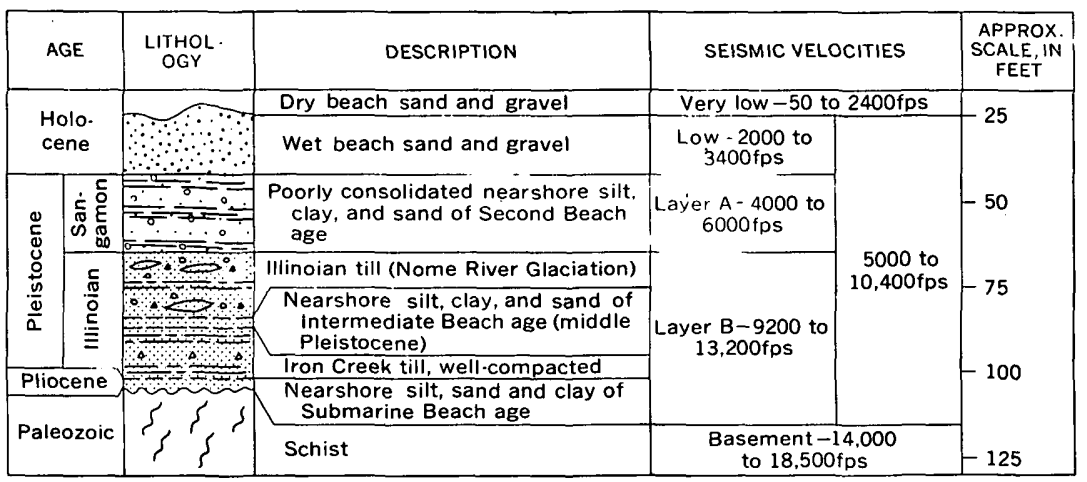

Figure 13.-Idealized cross sections and stratigraphic column of Nome beach and tundra seismic-investigations areas, constructed from observed geology and seismic data. 
the position of a former channel of the Snake River and the positions of several other channels not anticipated. These channels have not been tested by drilling, but it is entirely possible that they may prove to contain workable gold placers.

\section{REFERENCES CITED}

Brooks, A. H., Richardson, G. B., and Collier, A. J., 1901, Reconnaissances in the Cape Nome and Norton Bay regions, Alaska, in 1900: U.S. Geological Survey (special pub.), $222 \mathrm{p}$.

Collier, A. J., Hess, F. L., Smith, P. S., and Brooks, A. H., 1908, The gold placers of parts of Seward Peninsula, Alaska, including the Nome, Council, Kougarok, Port Clarence, and Goodhope precincts: U.S. Geol. Survey Bull. 328, 343 p.

Dix, C. H., 1940, Seismic prospecting for oil : New York, Harper \& Bros., 414 p.

Dobrin, M. B., 1960, Introduction to geophysical prospecting, 2d ed. : New York, MeGraw-Hill Book Co., 446 p.

Griffiths, D. H., and King, R. F., 1965, Applied geophysics for engineers and geologists : New York, Pergamon Press, 223 p.

Hodgson, J. H., 1964, Earthquakes and earth structures: Englewood, N.J., Prentice-Hall, Irc., $166 \mathrm{p}$.

Hopkins, D. M., 1967, Quaternary marine transgressions in Alaska, in Hopkins, D. M., ed, The Bering land bridge: Stanford, Calif., Stanford Univ. Press, p. $45-90$.

Hopkins, D. M., MacNeil, F. S., and Leopold, E. B., 1960, The coastal plain at Nome, Alaska-A Late Cenozoic type section for the Bering Strait region: Internat. Geol. Cong., 21st, Copenhagen, 1960, pt. 4, p. 46-57.

MacNeil, F. S., Mertie, J. B., Jr., and Philsby, H. A., 1943, Marine invertebrate faunas of the buried beaches near Nome, Alaska: Jour. Paleontology, v. 17, no. 1 , p. 69-96.

Moffit, F. H., 1913, Geology of the Nome and Grand Central quadrangles, Alaska: U.S. Geol. Survey Bull. 533, 140 p.

Nettleton, L. L., 1952, Geophysical prospecting for oil : New York, McGraw-Hill Book Co., 444 p. 